\title{
X-RAY CRYSTAL STRUCTURE OF $[2,7,12,17-$ TETRAPROPYLPORPHYCENATO|PLATINUM(II). A COMPARISON OF NICKEL(II) AND PLATINUM(II) PORPHYCENE
}

\author{
CHI-MING CHE, * KUNG-KAI CHEUNG,* ZAO-YING LI $\dagger$ and KWOK-YIN WONG $\dagger$ \\ Department of Chemistry, The University of Hong Kong, Pokfulam Road, Hong Kong
}

and

\section{CHIH-CHIEH WANG and YU WANG}

Department of Chemistry, National Taiwan University, Taipei, Taiwan

(Received 17 January 1994 ; accepted 4 March 1994)

\begin{abstract}
The synthesis, electronic structure and X-ray crystal analysis of [Pt(TPrPc)] $\left(\mathrm{H}_{2} \mathrm{TPrPc}=2,7,12,17\right.$-tetrapropylporphycene $)$ are described. The structure of [Pt(TPrPc)] is similar to that of its $\mathrm{Ni}^{\mathrm{II}}$ analogue except for the increase in the distance between the two bipyrrole moieties.
\end{abstract}

Porphycene and its derivatives, first synthesized by Vogel and co-workers, ${ }^{1}$ have attracted our interest for their intriguing photoluminescent properties. An important feature of these molecules is the small and rectangular cavity of the macrocycle, which may lead to a non-planar conformation upon complexation with large metal ions. Although different metalloporphycene complexes have been reported, ${ }^{2-4}$ only the $\mathrm{X}$-ray crystal structure of $\mathrm{Ni}(\mathrm{TPrPc})$ has been elucidated. ${ }^{1}$ Here we describe the molecular structure of $\mathrm{Pt}(\mathrm{TPrPc})$. A direct comparison between its electronic structure with that of the $\mathrm{Ni}^{\mathrm{II}}$ analogue through Extended Hückel Molecular Orbital Calculation is presented.

\section{EXPERIMENTAL}

\section{Reagents and materials}

2,7,12,17-Tetrapropylporphycene ${ }^{1}$ and $\mathrm{Pt}\left(\mathrm{C}_{6} \mathrm{H}_{5}\right.$ $\mathrm{CN})_{2} \mathrm{Cl}_{2}{ }^{5}$ were prepared according to literature procedures.

* Authors to whom correspondence should be addressed.

$\dagger$ Present address: Department of Applied Biology and Chemical Technology, Hong Kong Polytechnic, Hungham, Kowloon, Hong Kong.

\section{Spectral measurements}

${ }^{1} \mathrm{H}$ NMR spectra were recorded on a JEOL JNMGSX 270 Fourier Transform NMR spectrometer $(270 \mathrm{MHz})$ and the chemical shifts $(\delta, \mathrm{ppm})$ were reported with reference to tetramethylsilane (TMS). UV-vis spectra were recorded on a Milton Roy Spectronic 3000 diode array spectrophotometer. IR spectra were obtained on a Nicolet 20 SXCFT-IR spectrometer.

\section{Preparation of $\mathrm{Pt}(\mathrm{TPrPc})$}

A solution of $\mathrm{H}_{2} \mathrm{TPrPc} \quad(30 \mathrm{mg})$ and $\mathrm{Pt}\left(\mathrm{C}_{6} \mathrm{H}_{5} \mathrm{CN}\right)_{2} \mathrm{Cl}_{2}(45 \mathrm{mg})$ in benzonitrile $\left(30 \mathrm{~cm}^{3}\right)$ was refluxed with stirring under nitrogen for $6 \mathrm{~h}$. After cooling, the solvent was removed under reduced pressure. The residue was redissolved in toluene $\left(3 \mathrm{~cm}^{3}\right)$, then loaded on an alumina column and eluted with toluene. The leading blue band was collected and methanol $\left(10 \mathrm{~cm}^{3}\right)$ was added. Removal of solvent on a rotary evaporator led to precipitation of the product (yield : $80 \%$ ). Crystals suitable for X-ray crystal analysis were obtained by recrystallization from dichloromethane-methanol. Found: $\mathrm{C}, 57.1 ; \mathrm{H}, 5.4 ; \mathrm{N}, 8.4$. Calc. for 
$\mathrm{C}_{32} \mathrm{H}_{36} \mathrm{~N}_{4} \mathrm{Pt}$ : C, 57.2; $\mathrm{H}, 5.4 ; \mathrm{N}, 8.3 \%$. UV-vis $\left[\lambda_{\max }, \mathrm{nm}(\varepsilon)\right]$ in $\mathrm{CHCl}_{3}: 275(39,800), 382(78,600)$, $553(15,200)$ sh, $593(36,300), 636(6770)$ sh. ${ }^{1} \mathrm{H}$ NMR $\left(270 \mathrm{MHz}, \mathrm{CDCl}_{3}\right): \delta 9.58(\mathrm{~s}, 9,10,19,20$, $4 \mathrm{H}) ; 8.85(\mathrm{~s}, 3,6,13,16,4 \mathrm{H}) ; 3.99\left(\mathrm{t}, \alpha-\mathrm{CH}_{2}, 8 \mathrm{H}\right)$; $2.36\left(\mathrm{~m}, \beta-\mathrm{CH}_{2}, 8 \mathrm{H}\right) ; 1.35\left(\mathrm{t}, \mathrm{CH}_{3}, 12 \mathrm{H}\right)$.

\section{$X$-ray structure determination for $\mathrm{Pt}(\mathrm{TPrPc})$}

Crystal data. $\mathrm{C}_{32} \mathrm{H}_{36} \mathrm{~N}_{4} \mathrm{Pt}, M=671.79$, triclinic, space group $P . \overline{1} \quad a=5.415(1), \quad b=9.785(5)$, $c=12.668(4) \quad \AA, \quad \alpha=98.61(2), \quad \beta=94.16(2)$, $\gamma=90.65(2)^{\circ}, \quad U=661.7(1.0) \quad \AA^{3}, \quad Z=1$, $D_{c}=1.686 \mathrm{~g} \mathrm{~cm}^{-3}, F(000)=334, \mu=53.83 \mathrm{~cm}^{-1}$. Intensity data were collected at $24^{\circ} \mathrm{C}$ on an Enraf-Nonius CAD4 diffractometer with graphitemonochromated Mo- $K_{\alpha}(\lambda=0.71073 \AA)$ radiation. The dimensions of the crystal were $0.08 \times 0.10 \times 0.28 \mathrm{~mm}$. A total of 3191 unique reflections were measured, of which 2567 were unique and 2437 with $I_{0}>3 \sigma\left(I_{0}\right)$ were considered observed. No decay was observed in the three standard reflections. Lorentz and polarization factors were applied to the data, and empirical absorption corrections based on the $\psi$-scan of five strong reflections were applied. The centrosymmetric space group was used as there was one molecule in the unit cell. The structure was solved by full matrix least-squares methods. Convergence for 169 parameters was reached with $(\Delta / \sigma)_{\max }=0.01$ at $R=0.051, R_{\mathrm{w}}=0.057$ and $S=1.536$ for 2437 reflections. A final difference Fourier map showed positive peaks of $1.2-2.0 \mathrm{e} \AA^{-3}$ in the vicinity of the platinum atom but was otherwise featureless, with positive and negative peaks of 0.68 and $0.93 \mathrm{e}^{-3}$, respectively. All calculations were performed on a MicroVAX II computer using the Enraf-Nonius SDP-1985 programs. Selected bond lengths and angles are given in Table 1.

\section{Molecular orbital calculation}

EHMO calculations were carried out using the geometric parameters from the $\mathrm{X}$-ray diffraction data. The basis functions of platinum were taken from the literature. ${ }^{6 \mathrm{a}}$ Molecular orbital calculations were made with the ICON program. ${ }^{6 b}$

\section{RESULTS AND DISCUSSION}

The synthesis of $[\mathrm{Pt}(\mathrm{TPrPc})]$ has been reported previously in the literature. ${ }^{4}$ Its UV-vis spectrum in $\mathrm{CHCl}_{3}$, shown in Fig. 1, closely resembles that of $\mathrm{Ni}(\mathrm{TPrPc})$ reported by Vogel and co-workers, ${ }^{7}$ with only a slight red shift of all absorption bands.

The ${ }^{1} \mathrm{H}$ NMR spectra of the two [M(TPrPc)] $(\mathrm{M}=\mathrm{Ni}, \mathrm{Pt})$ complexes are very similar. Changing the central metal from platinum to nickel causes only a slight upfield shift of the $9,10,19$ and 20 proton resonances.

Table 1. Selected bond distances $(\AA)$ and bond angles $\left({ }^{\circ}\right)$ in $\operatorname{Pt}(\mathrm{TPrPc})$

\begin{tabular}{llll}
\hline $\mathrm{Pt}-\mathrm{N}(1)$ & $1.983(7)$ & $\mathrm{C}(3)-\mathrm{C}(11)$ & $1.50(1)$ \\
$\mathrm{Pt}-\mathrm{N}(2)$ & $1.980(7)$ & $\mathrm{C}(4)-\mathrm{C}(5)$ & $1.40(1)$ \\
$\mathrm{N}(1)-\mathrm{C}(1)$ & $1.37(1)$ & $\mathrm{C}(5)-\mathrm{C}(6)$ & $1.40(1)$ \\
$\mathrm{N}(1)-\mathrm{C}(4)$ & $1.36(1)$ & $\mathrm{C}(6)-\mathrm{C}(7)$ & $1.38(1)$ \\
$\mathrm{C}(1)-\mathrm{C}(2)$ & $1.41(1)$ & $\mathrm{C}(11)-\mathrm{C}(12)$ & $1.52(1)$ \\
$\mathrm{C}(2)-\mathrm{C}(3)$ & $1.37(1)$ & $\mathrm{C}(12)-\mathrm{C}(13)$ & $1.53(1)$ \\
$\mathrm{C}(3)-\mathrm{C}(4)$ & $1.45(1)$ & $\mathrm{N}(1)-\mathrm{N}(2)$ & 3.02 \\
& & $\mathrm{~N}(1)-\mathrm{N}(2)^{a}$ & 2.56 \\
& & & \\
$\mathrm{~N}(1)-\mathrm{Pt}-\mathrm{N}(2)$ & $99.5(3)$ & $\mathrm{C}(2)-\mathrm{C}(3)-\mathrm{C}(4)$ & $106.4(7)$ \\
$\mathrm{Pt}-\mathrm{N}(1)-\mathrm{C}(1)$ & $115.3(6)$ & $\mathrm{C}(2)-\mathrm{C}(3)-\mathrm{C}(11)$ & $127.9(9)$ \\
$\mathrm{Pt}-\mathrm{N}(1)-\mathrm{C}(4)$ & $137.1(7)$ & $\mathrm{C}(4)-\mathrm{C}(3)-\mathrm{C}(11)$ & $125.7(7)$ \\
$\mathrm{C}(1)-\mathrm{N}(1)-\mathrm{C}(4)$ & $107.6(8)$ & $\mathrm{N}(1)-\mathrm{C}(4)-\mathrm{C}(3)$ & $108.6(8)$ \\
$\mathrm{Pt}-\mathrm{N}(2)-\mathrm{C}(7)$ & $137.2(6)$ & $\mathrm{N}(1)-\mathrm{C}(4)-\mathrm{C}(5)$ & $128.0(8)$ \\
$\mathrm{Pt}-\mathrm{N}(2)-\mathrm{C}(10)$ & $114.3(5)$ & $\mathrm{C}(3)-\mathrm{C}(4)-\mathrm{C}(5)$ & $123.4(7)$ \\
$\mathrm{C}(7)-\mathrm{N}(2)-\mathrm{C}(10)$ & $108.4(8)$ & $\mathrm{C}(4)-\mathrm{C}(5)-\mathrm{C}(6)$ & $135.0(8)$ \\
$\mathrm{N}(1)-\mathrm{C}(1)-\mathrm{C}(2)$ & $109.4(7)$ & $\mathrm{C}(5)-\mathrm{C}(6)-\mathrm{C}(7)$ & $134.7(8)$ \\
$\mathrm{C}(1)-\mathrm{C}(2)-\mathrm{C}(3)$ & $108.0(8)$ & $\mathrm{C}(11)-\mathrm{C}(12)-\mathrm{C}(13)$ & $111.9(8)$ \\
& & &
\end{tabular}

${ }^{a}$ At $-x,-y,-z$. 


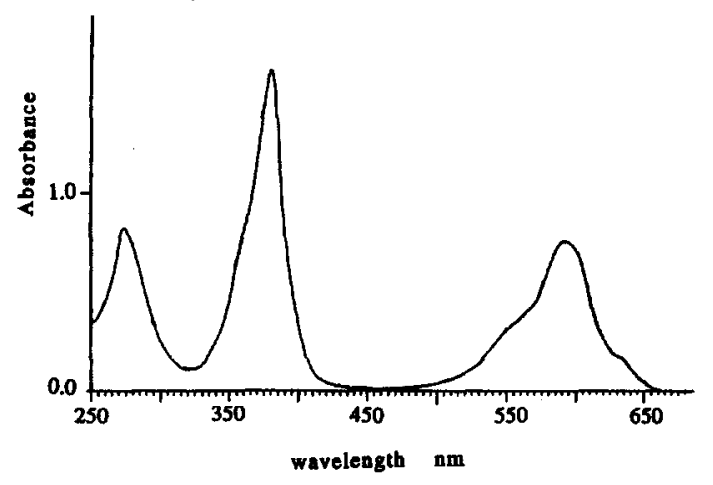

Fig. 1. UV-vis spectrum of $\mathrm{Pt}(\mathrm{TPrPc})$ in $\mathrm{CHCl}_{3}$.

\section{$X$-ray structure}

Figure 2 shows a perspective view of the $\mathrm{Pt}$ (TPrPc) molecule. Like $\mathrm{H}_{2}$ TPrPc and Ni(TPrPc), ${ }^{1}$ Pt(TPrPc) is also centrosymmetric in the crystal. The platinum atom and the four pyrrole nitrogens are co-planar. The conformation of the propyl substituents is similar to that of the free ligand and the Ni(TPrPc) complex.

Despite the overall structural similarity of $\mathrm{Ni}(\mathrm{T}$ PrPc) and Pt(TPrPc), the replacement of $\mathrm{Ni}^{\mathrm{II}}$ by $\mathbf{P t}^{\mathrm{II}}$ distorts the porphycene skeleton considerably, with the edge lengths of the rectangle constituted by the four nitrogens most significantly affected. The difference between $N(1)-N(2)$ and $\mathrm{N}(1)-\mathrm{N}\left(2^{*}\right)$ distances is $0.25 \AA$ for $\mathrm{Ni}(\mathrm{TPrPc}){ }^{1}$
This value becomes $0.46 \AA$ in the case of Pt(TPrPc). The average $\mathrm{Pt}-\mathrm{N}$ distance of $1.981(7) \AA$ is slightly longer than the average $\mathrm{Ni}-\mathrm{N}$ distance of $1.895 \AA$ in Ni(TPrPc). This can be ascribed to the fact that the $\mathbf{P t}^{\mathrm{II}}$ ion is larger than the $\mathrm{Ni}^{\mathrm{II}}$ ion.

Obviously, replacement of the $\mathrm{Ni}^{\mathrm{II}}$ ion by the larger $\mathrm{Pt}^{\mathrm{II}}$ ion leads to expansion of the cavity of the porphycene ligand. Note that the $\mathrm{N}(1)-\mathrm{N}\left(2^{*}\right)$ distance in $\mathrm{Pt}(\mathrm{TPrPc})$ is 2.559 (7) $\AA$, which is comparable to the value of $2.554(4) \AA$ in Ni(TPrPc). ${ }^{1}$ However, the $\mathrm{N}(1)-\mathrm{N}(2)$ distance of $3.025(7) \AA$ is considerably longer than the corresponding distance of $2.80(4) \AA$ in $\mathrm{Ni}(\mathrm{TPrPc})$. Moreover, the $\mathrm{N}(1)-\mathrm{Pt}-\mathrm{N}(2)$ angle was found to be $99.5(3)^{\circ}$, which is markedly larger than the $95.3(3)^{\circ}$ value in $\mathrm{Ni}(\mathrm{TPrPc})$. This indicates that expansion of the

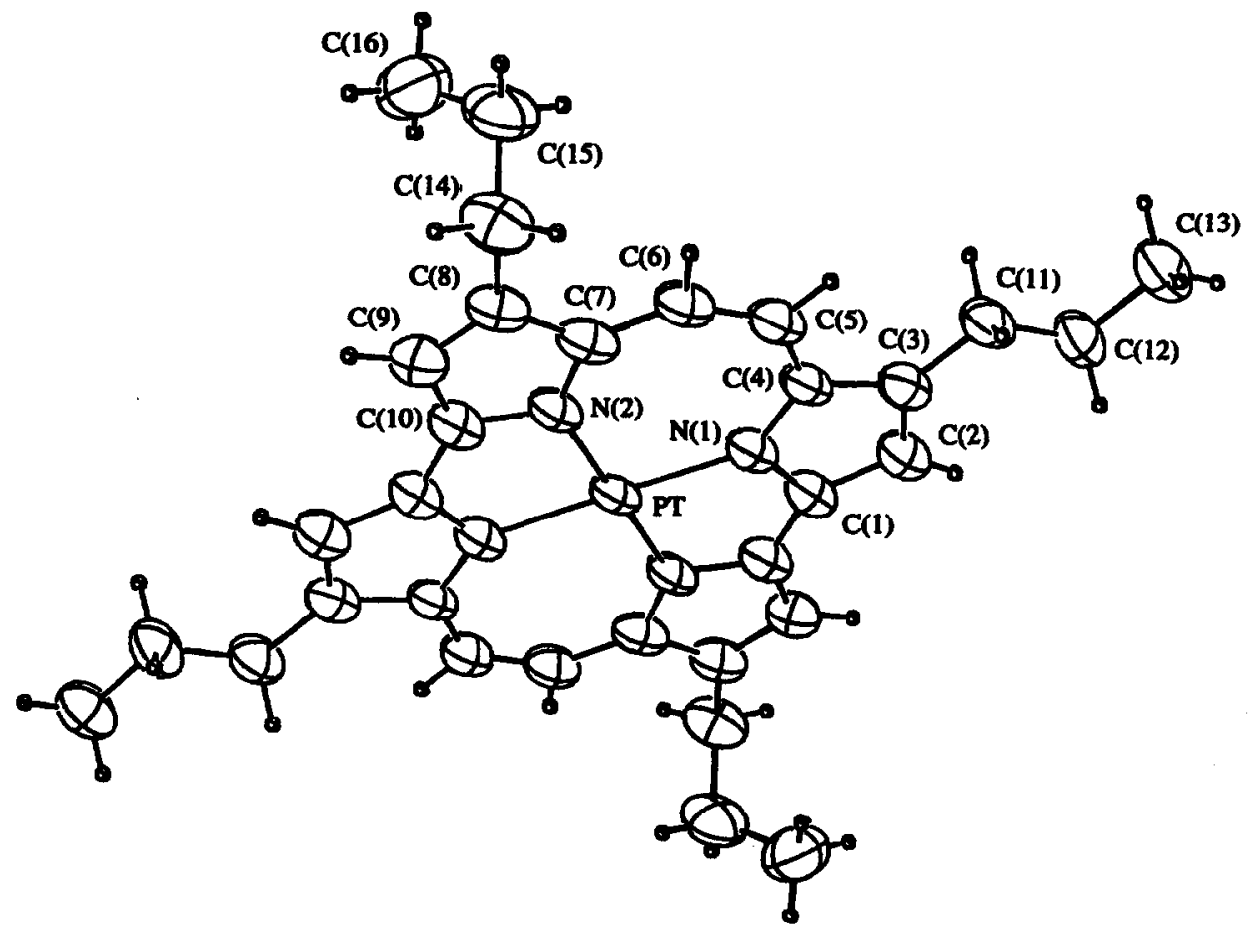

Fig. 2. A perspective drawing of $\mathrm{Pt}(\mathrm{TPrPc})$ with the atomic numbering scheme. 


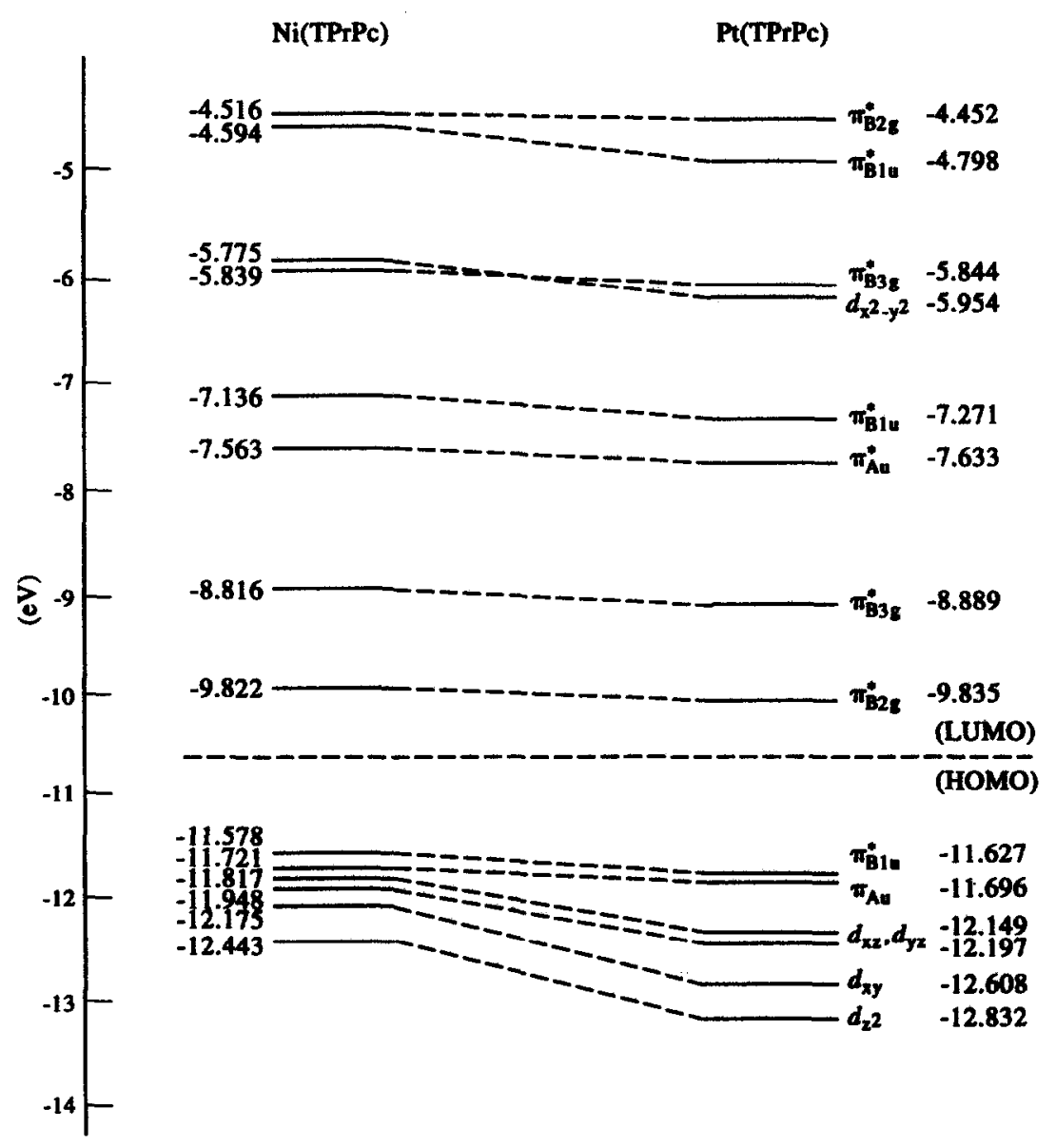

Fig. 3. Relative energy level diagram of $[\mathrm{Ni}(\mathrm{TPrPc})]$ and $[\mathrm{Pt}(\mathrm{TPrPc})]$ based on Extended Hückel Molecular Orbital Calculation.

cavity makes the distance between the two bipyrrole moieties remarkably longer but hardly changes the distance between the two pyrrole groups of each bipyrrole moiety.

The laterally displaced planar molecules form stacks at an interplanar distance of $3.51 \AA$ compared with $3.45 \AA$ in $[\mathrm{Ni}(\mathrm{TPrPc})]$.

\section{Molecular orbital calculation}

In their previous work, Fajer and co-workers briefly mentioned the energy gap between the HOMO and LUMO of [Ni(TPrPc)] based on Extended Hückel Molecular Orbital Calculation. ${ }^{8}$ However, the detail of the relative energy level diagram has not been reported. In this work, similar studies have been performed on both the $\mathrm{Ni}^{\mathrm{II}}$ and $\mathrm{Pt}^{\mathrm{II}}$ systems and a comparison of the energy level diagrams between the two systems is depicted in Fig. 3. On going from $\mathrm{Ni}^{\mathrm{II}}$ to $\mathrm{Pt}^{\mathrm{II}}$, the two lowest energy unoccupied molecular orbitals remain unchanged. For [Pt(TPrPc)], the two highest occupied molecular orbitals are still the $\Pi_{B 1 u}$ and $\Pi_{A u}$ of the porphycene ligand, but are nearly degenerate. Changing the metal ion from $\mathrm{Ni}^{\mathrm{II}}$ to $\mathrm{Pt}^{\mathrm{II}}$ leads to a larger energy gap between the ligand $\left(\Pi_{B 1 u}\right.$ and $\left.\Pi_{A u}\right)$ and the metal $d_{x z}, d_{y z}$ orbitals. It can be perceived that the lowest energy dipole-allowed transition, $\left(\Pi_{B 1 u}, \Pi_{A u}\right) \rightarrow \pi_{B 2 g}^{*}$ has lesser metal-to-ligand charge transfer character in the $\mathrm{Pt}^{\mathrm{II}}$ case.

Acknowledgements-We acknowledge support from The University of Hong Kong and the National Science Council of Taiwan. C. M. C. is grateful for a visiting Professorship administered by the National Taiwan University.

\section{REFERENCES}

1. E. Vogel, M. Balci, K. Pramod, P. Koch, J. Lex and O. Ermer, Angew. Chem., Int. Edn Engl. 1987, 26, 928.

2. E. Vogel, Pure Appl. Chem. 1990, 62, 557.

3. Z. Y. Li, J. S. Huang, C. M. Che and C. K. Chang, Inorg. Chem. 1992, 31, 2670.

4. M. Toporowicz, H. Ofir, H. Levanon, E. Vogel, M. Köcher, K. Pramod and R. W. Fessenden, Photochem. Photobiol. 1989, 50, 37. 
5. P. Braunstein, R. Bender and J. Jud, Inorg. Synth. $\quad$ 7. J. Waluk, M. Müller, P. Swiderek, M. Köcher, E. $1989,26,341$.

6. (a) C. Janiak and R. Hoffmann, Inorg. Chem. 1989, 28, 2743. (b) J. Howell, A. Rossi, D. Wallacer, K. Haraki and R. Hoffmann, ICON Programs, Quantum Chemistry Program University of Indiana Exchange Vogel, G. Hohlnier and J. Michl, J. Am. Chem. Soc. $1991,113,5511$.

8. M. W. Renner, A. Forman, W. Wu, C. K. Chang and J. Fajer, J. Am. Chem. Soc. 1989, 111, 8618. (1977). 